\title{
Determinants of arsenic methylation efficiency and urinary arsenic level in pregnant women in Bangladesh
}

Shangzhi Gao', Pi-l Lin', Golam Mostofa², Quazi Quamruzzaman², Mahmudur Rahman², Mohammad Lutfar Rahman ${ }^{3}$, Li Su', Yu-mei Hsueh ${ }^{4,5}$, Marc Weisskopf ${ }^{6}$, Brent Coull ${ }^{7}$ and David Chistopher Christiani ${ }^{1,8^{*}}$ (D)

\begin{abstract}
Background: Prenatal inorganic arsenic (iAs) exposure is associated with pregnancy outcomes. Maternal capabilities of arsenic biotransformation and elimination may influence the susceptibility of arsenic toxicity. Therefore, we examined the determinants of arsenic metabolism of pregnant women in Bangladesh who are exposed to high levels of arsenic.

Methods: In a prospective birth cohort, we followed 1613 pregnant women in Bangladesh and collected urine samples at two prenatal visits: one at 4-16 weeks, and the second at 21-37 weeks of pregnancy. We measured major arsenic species in urine, including iAs (iAs\%) and methylated forms. The proportions of each species over the sum of all arsenic species were used as biomarkers of arsenic methylation efficiency. We examined the difference in arsenic methylation using a paired t-test between first and second visits. Using linear regression, we examined determinants of arsenic metabolism, including age, BMI at enrollment, education, financial provider income, arsenic exposure level, and dietary folate and protein intake, adjusted for daily energy intake.

Results: Comparing visit 2 to visit 1, iAs\% decreased 1.1\% $(p<0.01)$, and creatinine-adjusted urinary arsenic level (U-As) increased 21\% (95\% Cl: 15, 26\%; $p<0.01)$. Drinking water arsenic concentration was positively associated with iAs\% at both visits. When restricted to participants with higher adjusted urinary arsenic levels (adjusted U-As > $50 \mathrm{\mu g} / \mathrm{g}$-creatinine) gestational age at measurement was strongly associated with DMA\% $(\beta=0.38, p<0.01)$ only at visit 1. Additionally, DMA\% was negatively associated with daily protein intake $(\beta=-0.02, p<0.01)$ at visit 1 , adjusting for total energy intake and other covariates.
\end{abstract}

Conclusions: Our findings indicate that arsenic metabolism and adjusted U-As level increase during pregnancy. We have identified determinants of arsenic methylation efficiency at visit 1.

Keywords: Environmental arsenic exposure, Arsenic metabolism, Urinary arsenic metabolites, Pregnancy, Reproductive health

\footnotetext{
* Correspondence: dchris@hsph.harvard.edu

${ }^{1}$ Department of Environmental Health, Harvard T.H. Chan School of Public

Health, 677 Huntington Ave, Boston, MA 02115, USA

${ }^{8}$ Pulmonary and Critical Care Unit, Department of Medicine, Massachusetts

General Hospital, 55 Fruit St, Boston, MA 02114, USA

Full list of author information is available at the end of the article
}

(c) The Author(s). 2019 Open Access This article is distributed under the terms of the Creative Commons Attribution 4.0 International License (http://creativecommons.org/licenses/by/4.0/), which permits unrestricted use, distribution, and reproduction in any medium, provided you give appropriate credit to the original author(s) and the source, provide a link to the Creative Commons license, and indicate if changes were made. The Creative Commons Public Domain Dedication waiver (http://creativecommons.org/publicdomain/zero/1.0/) applies to the data made available in this article, unless otherwise stated. 


\section{Introduction}

Inorganic arsenic (iAs) is a ubiquitous, naturally occurring environmental toxicant $[1,2]$. It has been linked to cancers [3] as well as increased risk of cardiovascular conditions [4], pregnancy complications [5], and developmental impairments [6]. iAs is a serious public health concern, as 200 million people worldwide are exposed to arsenic levels in drinking water that exceed the World Health Organization's recommended limit of $10 \mu \mathrm{g} / \mathrm{L}$ [7].

Pregnant women and developing fetuses are especially susceptible to arsenic exposure. Arsenic-related adverse health conditions during pregnancy include anemia, nausea, vomiting, and abnormal cramping [5, 8]. Prenatal arsenic exposure is linked to reduced gestation time, low birth weight, spontaneous abortion, stillbirth, neonatal mortality, and infant mortality [9-17]. Identifying factors that influence susceptibility to arsenic toxicity in mothers and children can provide knowledge for risk assessment and guide effective interventions in underserved arsenic-endemic areas.

The human body metabolizes arsenic primarily in the liver. Ingested arsenate $\left(\mathrm{iAs}^{\mathrm{V}}\right)$ is reduced to arsenite $\left(\mathrm{iAs}{ }^{\mathrm{III}}\right.$ ) by arsenate reductase, reacts with glutathione, and is enzymatically methylated to monomethylarsonous acid (MMA ${ }^{\mathrm{III}}$ ) by the methyl-donor S-adenosyl methionine (SAM). MMA ${ }^{\mathrm{III}}$ is either rapidly oxidized to monomethylarsonic acid $\left(\mathrm{MMA}^{\mathrm{V}}\right)$ or is involved in another cycle of methylation to form dimethylarsinous acid $\left(\mathrm{DMA}^{\mathrm{III}}\right)$, which is then oxidized to dimethylarsinic acid $\left(\mathrm{DMA}^{\mathrm{V}}\right)$ [18]. Among organic forms of arsenic, trivalent forms $\left(\mathrm{MMA}^{\mathrm{III}}\right.$ and $\mathrm{DMA}^{\mathrm{III}}$ ) are highly toxic and are reactive intermediates in the arsenic methylation pathway, while pentavalent forms $\left(\mathrm{MMA}^{\mathrm{V}}\right.$ and $\left.\mathrm{DMA}^{\mathrm{V}}\right)$ are less toxic and are more readily excreted in urine [19]. The valence of organic arsenics are difficult to detect in human urine [20], but the proportions of urinary excretion of iAs, monomethyl forms of arsenic (MMA), and dimethyl forms of arsenic (DMA) are often used to evaluate arsenic methylation in vivo [21].

Maternal arsenic methylation efficiency is an important modifier of arsenic-related negative pregnancy outcomes. A lower proportion of DMA and a higher proportion of iAs may indicate decreased arsenic methylation, leading to increased iAs retention [22-25]. Epidemiological studies show that arsenic methylation efficiency can modify arsenic-related health risks in exposed pregnant women, as a greater proportion of iAs in urine is associated with impaired fetal growth [26, 27].

Many factors influence methylation of arsenic species, including arsenic exposure level, age, body mass index (BMI), sex, smoking, genetic factors, ethnicity, pregnancy, breastfeeding [28, 29], and genetic factors [30]. In addition, growing evidence suggest that nutrition influences arsenic metabolism and the risk of arsenic-related morbidity. Pregnant women undergo complex hormonal changes, which influence a remarkable increase in arsenic methylation during pregnancy [31-33]. Patterns and determinants of arsenic metabolism need to be studied separately in pregnant women not only because of their changed metabolism, but also because developing children are especially vulnerable to external toxicants [32, 34].

Arsenic exposure from drinking water is most severe in Bangladesh, where it is estimated that $>19$ million people are exposed to $>5$ times the standard arsenic level [35]. Therefore, we studied arsenic methylation and excretion profiles during pregnancy in a Bangladeshi cohort, as well as factors that may influence arsenic metabolism, including gestational weeks, water arsenic exposure, socioeconomic variables, dietary folate intake, and dietary protein intake. Together, these observations seek to provide a better understanding of how pregnancy affects arsenic metabolism.

\section{Methods \\ Study population}

During 2008-2011, we recruited 1613 pregnant women from two study sites in Bangladesh: one located in Sirajdikhan, a suburban upazila (subdistrict) located $29 \mathrm{~km}$ south of the capital city Dhaka; and the other in Pabna, a rural upazila located $122 \mathrm{~km}$ northwest from Dhaka [5, 36]. Eligible participants were adult women ( $\geq 18$ years old) in their first trimester of pregnancy with a single fetus and who had a complete drinking water history that included tube well usage up to 6 months before pregnancy. These women participated in Dhaka Community Hospital's (DCH) prenatal health program and planned to deliver at home with a DCH-trained midwife or at a DCH hospital or clinic. All participating families signed the informed consent of the study.

At enrollment at weeks 4-16 of pregnancy (visit 1), trained DCH healthcare workers who lived in the local area administered questionnaires to collect information on participants' demographics, lifestyle, and medical condition. We collected a drinking water sample to assess arsenic exposure level, a urine sample to assess arsenic metabolite profile, and a toenail sample from each participant to assess long-term arsenic exposure levels. In addition, we provided all participants with a daily prenatal multivitamin with folate $(400 \mu \mathrm{g})$ upon recruitment. Due to ethical responsibility, we advised participants to avoid using contaminated water sources.

The follow-up visit (visit 2) occurred at 21-37 weeks of pregnancy. Healthcare workers collected another urine sample and administered a locally validated food frequency questionnaire (FFQ) to acquire habitual dietary intake information from the previous 12 months [37]. At the time of visit 2, 1438 participants remained 
in the study. Reasons for loss-of-follow-up included loss of contact $(N=6)$, participant dropout $(N=18)$, miscarriage $(N=131)$, stillbirth $(N=11)$, sample failure $(N=2)$, missing samples $(N=2)$, and twin pregnancy $(N=5)$. After visit 2, we followed participants until one-month post-partum and collected their drinking water samples and toenail samples again to assess the stability of arsenic exposure.

\section{Urinary arsenic metabolite concentration}

For each participant, we collected spot urine samples at both visits 1 and 2 to assess concentrations of arsenic methylation species, including $\mathrm{iAs}^{\mathrm{III}}, \mathrm{iAs}^{\mathrm{V}}$, MMA, and DMA. At the time of each visit, healthcare workers provided each participant a urine cup and instructed them how to obtain enough urine for analysis. Urine samples were sealed appropriately, brought to the local laboratory in iceboxes, and stored in a $-20^{\circ} \mathrm{C}$ freezer. Frozen urine samples were shipped to the Department of Public Health, School of Medicine at Taipei Medical University, Taiwan, where they were stored in $-80^{\circ} \mathrm{C}$ freezers. At the time of analysis, the urine samples were thawed at room temperature, sonicated for dispersion, filtered through a Sep-Pak C18 column (Mallinckrodt Baker Inc., NJ, USA), and transferred into $200-\mu \mathrm{L}$ aliquots. We separated arsenic species fractions by high-performance liquid chromatography (Waters 501, Waters Associates, Milford, MA, USA) with columns from Phenomenex (Nucleosil, Torrance, CA, USA). Concentrations of the 4 urinary arsenic metabolites were determined by hydride generator atomic absorption spectrometry (PerkinElmer, Waltham, MA, USA). Standard reference material no. 2670a was obtained from National Institute of Standards and Technology (Gaithersburg, MD, USA), and recovery rates for $\mathrm{iAs}^{\mathrm{III}}$, $\mathrm{iAs}{ }^{\mathrm{V}}, \mathrm{MMA}$, and DMA ranged 93.8$102.2 \%$. The limit of detection (LOD) for each urinary arsenic metabolite was three times the standard deviation of 10 runs: $0.02 \mu \mathrm{g} / \mathrm{L}, 0.06 \mu \mathrm{g} / \mathrm{L}, 0.07 \mu \mathrm{g} / \mathrm{L}$, and $0.10 \mu \mathrm{g} / \mathrm{L}$ for $\mathrm{iAs}^{\mathrm{III}}, \mathrm{iAs}^{\mathrm{V}}$, MMA, and DMA, respectively [38]. Numbers of observations under the LOD were 810 (50\%), $476(30 \%), 316(20 \%)$, and $1(0 \%)$ for visit 1; and 841(58\%), 374 (26\%), $172(12 \%)$, and 1 (0\%) for visit 2, for $\mathrm{iAs}^{\mathrm{III}}, \mathrm{iAs}^{\mathrm{V}}$, MMA, and DMA, respectively. We kept records below the LOD at their original value in our statistical analyses to provide the most information $[39,40]$. To control for urine dilution, we analyzed the concentration of urinary creatinine using a colorimetric assay (Modular P800, Roche Inc., Mannheim, Germany).

\section{Drinking water arsenic concentration}

To assess drinking water arsenic exposure level (DW-As) and its stability during the follow-up period, two repeated drinking water samples were collected as previously described [5] at visit 1 and one-month post-partum. Briefly, tube well water samples were collected from the participant's primary water source using well pumps after a oneminute purge. Samples were transferred to acid-washed polyethylene bottles and acidified with nitric acid for storage. Samples were then shipped to the laboratory (Environmental Laboratory Services, North Syracuse, NY, USA) and analyzed using a hybrid-generation technique of high-resolution inductively coupled process spectrometry (ICP-MS), following US Environmental Protection Agency method 200.8. Machines were sensitive to $1 \mu \mathrm{g} / \mathrm{L}$ of total arsenic concentration. Records with $<1 \mu \mathrm{g} / \mathrm{L}(N=329,20.5 \%)$ were assigned a value of $0.5 \mu \mathrm{g} / \mathrm{L}$ for statistical analyses (Kile et al. 2014).

\section{Toenail samples}

To assess long-term arsenic levels in the body, we collected and analyzed maternal toenail samples at visit 1 and at one-month post-partum as previously described $[9,41]$. Briefly, toenail samples were digested with Optima nitric acid (Thermo Fisher Scientific, Waltham, MA, USA) and analyzed using ICP-MS for total toenail arsenic concentration (T-As) [42].

\section{Dietary assessment}

To obtain recalled food consumption frequency during the previous 12 months, we administered a locally-validated semi-quantitative FFQ at visit 2 [37]. We included 42 common food items in Bangladesh from five categories: [1] cereal and bread [2]; vegetables [3]; legumes, pulses, and seeds [4]; fish, poultry, meat, and eggs; and [5] milk-based food items. The scale of consumption frequency and portion sizes were as previously described [37]. Trained technicians entered FFQ data. Daily protein intake (g/day), folate intake ( $\mu \mathrm{g} /$ day), and energy intake ( $\mathrm{kcal} /$ day) were estimated using the 2013 Food Composition Table for Bangladesh [43]. For dish types that were not available in the questionnaire table, nutrient compositions were calculated based on average weighted recipes provided by local dietitians at $\mathrm{DCH}$ using nutrient retention factors and yield factors in the Food Composition Table.

\section{Statistical analysis}

We adjusted urinary arsenic metabolite concentrations (mg/g-creatinine) by absolute concentration $(\mu \mathrm{g} / \mathrm{L})$ divided by urinary creatinine concentration $(\mathrm{mg} / \mathrm{dL})$. Adjusted total urinary arsenic was the sum of adjusted urinary arsenic metabolites. The proportion of each urinary arsenic metabolite (iAs ${ }^{\mathrm{III}} \%, \mathrm{iAs} \%$, MMA\%, and DMA\%) was calculated using its concentration divided by the sum of all urinary arsenic metabolite concentrations. The proportion of iAs (iAs\%) was the sum of $\mathrm{iAs}{ }^{\mathrm{III}} \%$ and $\mathrm{iAs}{ }^{\mathrm{V}_{\%}}$.

We used Wilcoxon signed-rank test to compare the percentages of arsenic species in urine between two visits and paired $\mathrm{t}$-tests to compare the log-transformed 
concentration of arsenic species, creatinine levels, and total urinary arsenic levels. We calculated Spearman correlations of urinary arsenic metabolites.

Linear regression models were used to examine potential determinants of arsenic metabolism biomarkers. iAs\%, MMA\%, and DMA\% were treated as separate outcome variables. Independent variables were age, BMI at enrollment, arsenic exposure level (adjusted U-As, continuous), education level (<secondary education or $\geq$ secondary education), monthly income of the financial provider, daily protein intake, daily folate intake, and daily energy intake tertiles (low/medium/high). We fitted each visit and study site to a separate model. Based on previous literature, variables that are likely to be correlated with exposure and outcome were considered in models. Analysis was applied to all mothers, as well as to a restricted sample of participants with adjusted U-As of $>50 \mu \mathrm{g} / \mathrm{g}$ creatinine. We chose a cut-off point of $50 \mu \mathrm{g} /$ g-creatinine because this level is around the 25th quantile of exposure (see Additional file 1: Table S1). Further, we excluded some outlying measurements from analysis (exclusion criteria: creatinine level $<10 \mathrm{mg} / \mathrm{dL}$ and adjusted U-As $>3000 \mu \mathrm{g} / \mathrm{g}$-creatinine).

We separately compared the whole study population $(N=1613)$ and participants with no missing data $(N=$ 1425 at visit $1 ; N=1420$ at visit 2 ). There were no significant differences in demographics or exposure level between the two study populations. All statistical analyses were performed with SAS software (version 9.4; SAS Institute Inc., Cary, NC, USA).

\section{Results}

Most participants were Bangladeshi homemakers (99\%), non-smokers $(100 \%)$, did not chew tobacco or betel nut (99\%), and reported physical activity during pregnancy as "on their feet all day but in a stationary position or only spend half the day moving around on their feet" (99\%). Detailed information about participants' demographics, lifestyle, and exposure information is shown in Table 1. Participants from Pabna had a higher average DW-As exposure level $(79.5 \pm 131.3 \mu \mathrm{g} / \mathrm{L})$ compared to participants from Sirajdikhan $(12.2 \pm 47.4 \mu \mathrm{g} / \mathrm{L})$. All participants reported taking prenatal vitamins with folate every day from visit 1 to visit 2 . There were no significant differences in demographics or exposure level between the sample of all enrolled mothers and completed cases.

Medians and 5th-95th percentiles of the proportions and concentrations of urinary arsenic metabolites at visit 1 and visit 2 are summarized in Table 2 . Results of Wilcoxon signed-rank tests and paired t-tests of difference in each arsenic metabolite between the two visits are shown in Table 3. Median iAs\% for all mothers decreased from $8.5 \%$ at visit 1 to $6.6 \%$ at visit
2 (mean change $=-1.1 \% ; p<0.01$ ), mainly due to decreased iAs ${ }^{\mathrm{III}} \%$ (mean change $=-1.6 \% ; p<0.01$ ). Median DMA\% for all mothers increased from $85.7 \%$ at visit 1 to $87.9 \%$ at visit 2 (mean change $=1.1 \%$; $p<0.01)$. No change was observed in MMA\% for all mothers.

Restricting analysis to only participants with adjusted U-As of $>50 \mu \mathrm{g} / \mathrm{g}$-creatinine, DMA\% increased during the first trimester and remained high in the mid-to-late gestational period for participants in both Sirajdikhan and Pabna (Fig. 1). The significance of the increase would be shown with later regression analysis results. Data from all mothers are shown in Additional file 1: Figure S1 Further, proportions of arsenic metabolites in urine were highly correlated at visit 1 and visit 2 (Fig. 2). The adjusted U-As were correlated between visit 1 and visit 2 (see Additional file 1: Figure S2). Total urinary arsenic excretion was associated with urinary creatinine excretion (see Additional file 1: Figure S3). Thus, we used adjusted U-As in continuing analyses. Median UAs increased from $77.6 \mathrm{mg} / \mathrm{g}$-creatinine at visit 1 to 90.4 $\mathrm{mg} / \mathrm{g}$-creatinine at visit 2 . The mean difference of $\log$ transformed U-As from visit 1 to visit 2 was $0.2(p<$ 0.01 ), and the average ratio of U-As of visit 2 over visit 1 was 1.2. Log-transformed DW-As from visit 1 to onemonth post-partum remained unchanged $(p=0.06$; average ratio $=1.08$ ). Log-transformed $\mathrm{T}$-As decreased from visit 1 to one-month post-partum, with an average ratio of $0.70(p<0.01)$.

The association between adjusted U-As and DW-As is shown in Fig. 3. Because participants in Sirajdikhan had high U-As levels despite low DW-AS levels, they seemed to have other sources of arsenic exposure in addition to drinking water. We applied a linear model for doseresponse relationship using data in Pabna, because participants in Pabna were less likely to be affected by other arsenic sources, resulting in a relationship of log (adjusted U-As $)=4.06+0.32 \times \log (\mathrm{DW}-\mathrm{As})$. Table 4 shows determinants affecting the proportions of urinary arsenic metabolites at visit 1 . When restricted to participants with adjusted U-As of $>50 \mu \mathrm{g} / \mathrm{g}$-creatinine, gestational age at measurement was strongly associated with DMA\% $(\beta=0.38, p<0.01)$. Maternal age was positively associated with DMA\% $(\beta=0.15, p=0.04)$. Maternal higher education level was negatively associated with iAs\% $(\beta=-1.16, p=0.03)$. Additionally, DMA\% was negatively associated with daily protein intake $(\beta=-$ $0.02, p<0.01$ ). Every $100 \mathrm{~g}$ of daily dietary protein was associated with a $2 \%$ decrease of DMA in participants' urine, adjusting for total energy intake and other covariates. Average iAs\% for low, medium, and high tertiles of protein intake was $8.8,9.3$, and $11.8 \%$, respectively. Average DMA\% for low, medium, and high tertiles of protein intake was $85.2,84.3$, and $84.9 \%$, respectively. 
Table 1 Characteristics of study participants in Sirajdikhan and Pabna upazilas, Bangladesh

\begin{tabular}{|c|c|c|c|}
\hline & Sirajdikhan $(N=879)$ & Pabna $(N=727)$ & All mothers $(N=1176)$ \\
\hline \multicolumn{4}{|l|}{ Years of age, visit $1^{a}$} \\
\hline & $22.8 \pm 4.1$ & $23.0 \pm 4.2$ & $22.9 \pm 4.2$ \\
\hline \multicolumn{4}{|l|}{ Education level ${ }^{\mathrm{b}}$} \\
\hline$<$ Secondary education & $446(51 \%)$ & 335 (46\%) & 781 (49\%) \\
\hline$\geq$ Secondary education & 431 (49\%) & $389(54 \%)$ & $820(51 \%)$ \\
\hline \multicolumn{4}{|l|}{ BMI, visit 1 (kg/m²) } \\
\hline & $21.0 \pm 3.3$ & $20.0 \pm 2.9$ & $21.0 \pm 3.0$ \\
\hline \multicolumn{4}{|l|}{$\begin{array}{l}\text { Financial provider's monthly } \\
\text { income (taka) }\end{array}$} \\
\hline Unknown & $9(1 \%)$ & $23(3 \%)$ & $32(2 \%)$ \\
\hline $0-2000$ & $5(1 \%)$ & $10(1 \%)$ & $15(1 \%)$ \\
\hline $2001-3000$ & $39(4 \%)$ & 197 (27\%) & $236(15 \%)$ \\
\hline $3001-4000$ & $178(20 \%)$ & $222(31 \%)$ & $400(25 \%)$ \\
\hline $4001-5000$ & $328(37 \%)$ & $167(23 \%)$ & 495 (31\%) \\
\hline $5000-6000$ & $190(22 \%)$ & $63(9 \%)$ & $253(16 \%)$ \\
\hline$>6000$ & $129(15 \%)$ & $44(6 \%)$ & $173(11 \%)$ \\
\hline \multicolumn{4}{|l|}{ Gestational weeks, visit 1} \\
\hline & $11.1 \pm 3.1$ & $11.4 \pm 3.0$ & $11 \pm 3.0$ \\
\hline \multicolumn{4}{|l|}{ Gestational weeks, visit 2} \\
\hline & $28.6 \pm 1.8$ & $29.3 \pm 1.9$ & $28.9 \pm 1.9$ \\
\hline \multicolumn{4}{|c|}{ Environmental smoke exposure } \\
\hline No & $555(63 \%)$ & $370(51 \%)$ & 925 (58\%) \\
\hline Yes & $322(37 \%)$ & 356 (49\%) & $678(42 \%)$ \\
\hline \multicolumn{4}{|l|}{$\begin{array}{l}\text { Number of glasses of } \\
\text { water drank per day }\end{array}$} \\
\hline & $7.7 \pm 2.3$ & $7.7 \pm 2.4$ & $8 \pm 2.0$ \\
\hline \multicolumn{4}{|l|}{$\begin{array}{l}\text { Drinking water arsenic } \\
\text { exposure categories }\end{array}$} \\
\hline Quartile 1: $\leq 0.89 \mu \mathrm{g} / \mathrm{L}$ & 309 (35\%) & 92 (13\%) & $401(25 \%)$ \\
\hline Quartile 2: 0.89-2 $\mu \mathrm{g} / \mathrm{L}$ & 397 (45\%) & $24(3 \%)$ & $421(26 \%)$ \\
\hline Quartile 3: 2-33 $\mu \mathrm{g} / \mathrm{L}$ & $103(12 \%)$ & $278(38 \%)$ & 381 (24\%) \\
\hline Quartile 4: > $33 \mu \mathrm{g} / \mathrm{L}$ & $69(8 \%)$ & $332(46 \%)$ & $401(25 \%)$ \\
\hline \multicolumn{4}{|c|}{ Drinking water arsenic $(\mu \mathrm{g} / \mathrm{L})$, visit 1} \\
\hline & $12.1 \pm 47.4$ & $79.5 \pm 131$ & $42.6 \pm 101$ \\
\hline Median & 1.4 & 27.0 & 2.0 \\
\hline \multicolumn{4}{|c|}{$\begin{array}{l}\text { Drinking water arsenic }(\mu \mathrm{g} / \mathrm{L}) \text {, } \\
\text { one-month post-partumc }\end{array}$} \\
\hline & $6.8 \pm 32.5$ & $78.9 \pm 133$ & $42.7 \pm 103$ \\
\hline Median & 1.0 & 26.0 & 1.8 \\
\hline \multicolumn{4}{|c|}{ Maternal toenail arsenic $(\mu \mathrm{g} / \mathrm{g})$, visit 1} \\
\hline & $2.2 \pm 3.2$ & $4.8 \pm 5.9$ & $3.4 \pm 4.9$ \\
\hline Median & 1.1 & 2.5 & 1.7 \\
\hline \multicolumn{4}{|c|}{$\begin{array}{l}\text { Maternal toenail arsenic }(\mu \mathrm{g} / \mathrm{g}) \text {, } \\
\text { one-month post-partum }^{\mathrm{d}}\end{array}$} \\
\hline & $1.8 \pm 3.6$ & $3.6 \pm 4.2$ & $2.7 \pm 4.0$ \\
\hline Median & 0.7 & 2.0 & 1.2 \\
\hline
\end{tabular}


Table 1 Characteristics of study participants in Sirajdikhan and Pabna upazilas, Bangladesh (Continued)

\begin{tabular}{llll}
\hline & Sirajdikhan $(N=879)$ & Pabna $(N=727)$ & All mothers $(N=1176)$ \\
\hline Daily dietary folate intake $(\mu \mathrm{g})$ & $268 \pm 96.7$ & $396 \pm 103$ & $327 \pm 118$ \\
Daily dietary protein intake $(\mathrm{g})$ & $131 \pm 47.9$ & $219.3 \pm 60.0$ & $172 \pm 69.6$ \\
Daily energy intake $(\mathrm{kcal})$ & $3195 \pm 978$ & $3234 \pm 763$ & $3214 \pm 885$ \\
\hline
\end{tabular}

${ }^{a}$ Continuous variables are presented as mean \pm standard deviation

${ }^{b}$ Categorical variables are presented as number of participants (percentage)

'Pearson's correlation of drinking water arsenic concentration between the first visit and one-month post-partum is 0.72 ( $p<0.0001)$

d Pearson's correlation of toenail arsenic concentration between the first visit and one-month post-partum is 0.84

At visit 2, DMA\% was only associated with adjusted U-As. We did not find other determinants of arsenic methylation efficiency at visit 2 (see Additional file 1: Table S2).

\section{Discussion}

Our findings suggest that arsenic methylation efficiency increases during pregnancy. At both visits, higher doses of arsenic were associated with increased iAs\% and MMA\%, as well as decreased DMA\%, which is consistent with previous studies [44-46]. Further, other determinants affected arsenic methylation efficiency only in early gestational periods.
Our study included two study sites in Bangladesh, which were chosen for two reasons: they are under the service area of our collaborator, and they have different exposure levels of arsenic. Sirajdikhan has lower arsenic exposure levels, while Pabna has higher arsenic exposure levels. There were also differences in culture and dietary patterns between the two sites. A group of participants in Sirajdikhan had high levels of adjusted U-As despite low DW-As levels, indicating that these individuals were likely exposed to arsenic from their diets. For example, arsenic can accumulated in rice and rice is one of the common food of Bangladeshi in a daily basis $[47,48]$. Participants may also exposed to organic forms of

Table 2 Urinary arsenic metabolites of study participants in Sirajdikhan and Pabna at visits 1 and 2

\begin{tabular}{|c|c|c|c|c|c|c|}
\hline & \multicolumn{2}{|l|}{ Sirajdikhan } & \multicolumn{2}{|l|}{ Pabna } & \multicolumn{2}{|l|}{ All mothers } \\
\hline & Visit 1 & Visit 2 & Visit 1 & Visit 2 & Visit 1 & Visit 2 \\
\hline N & 879 & 783 & 727 & 662 & 1606 & 1445 \\
\hline ¡As ${ }^{\mathrm{II}} \%{ }^{\mathrm{a}}$ & $0(0,12.6)$ & $0(0,9.9)$ & $3.1(0,17.8)$ & $0(0,11.5)$ & $0(0,15.9)$ & $0(0,10.6)$ \\
\hline $\mathrm{i} A s^{V_{\%}} \%$ & $1.1(0,20.9)$ & $1.8(0,26.2)$ & $3.8(0,18.6)$ & $4(0,20)$ & $2.1(0,19.6)$ & $2.6(0,23.6)$ \\
\hline ¡As\% & $5.7(0,24.1)$ & $5.3(0,27.7)$ & $11.2(1.4,24)$ & $8(0,22.1)$ & $8.5(0,24)$ & $6.6(0,25.4)$ \\
\hline MMA\% & $3.5(0,13.4)$ & $4.3(0,11.8)$ & $6(0.6,13.1)$ & $5.6(0.1,11.3)$ & $4.9(0,13.2)$ & $4.8(0,11.6)$ \\
\hline DMA\% & $89.5(66.9,100)$ & $89.6(66,99.9)$ & $82(66.2,95.6)$ & $85.8(68.9,98)$ & $85.7(66.6,100)$ & $87.9(67.3,99.5)$ \\
\hline$i \mathrm{As} \mathrm{s}^{\prime \prime \prime}, \mu \mathrm{g} / \mathrm{L}$ & $0(0,8.8)$ & $0(0,7.7)$ & $1.7(0,57.9)$ & $0(0,27.8)$ & $0(0,28.9)$ & $0(0,16.7)$ \\
\hline $\mathrm{i} A s^{v}, \mu \mathrm{g} / \mathrm{L}$ & $0.2(0,8.8)$ & $0.5(0,12)$ & $2.5(0,36)$ & $2.1(0,51.9)$ & $0.6(0,21.8)$ & $0.9(0,22.5)$ \\
\hline ¡As, $\mu \mathrm{g} / \mathrm{L}$ & $0.7(0,17.8)$ & $1.1(0,17.9)$ & $7.5(0.2,81.8)$ & $4.9(0,75.9)$ & $2.5(0,52.2)$ & $2.4(0,39.1)$ \\
\hline $\mathrm{MMA}, \mu \mathrm{g} / \mathrm{L}$ & $0.5(0,10.6)$ & $1.1(0,11)$ & $4.1(0.1,42.5)$ & $3.4(0,35.1)$ & $1.3(0,30.3)$ & $1.7(0,21.5)$ \\
\hline DMA, $\mu \mathrm{g} / \mathrm{L}$ & $10.9(1.9,121)$ & $20.5(3.6,128)$ & $54.2(8.8,431)$ & $50.2(7.4,371)$ & $22.5(2.6,297)$ & $30(4.5,259)$ \\
\hline U-As & $12.2(2,147)$ & $23.7(4.3,151)$ & $69.9(9.7,531)$ & $63.2(8,480)$ & $26.5(2.9,376)$ & $35.2(5.1,325)$ \\
\hline U-creatinine, mg/dL & $23.1(6,113)$ & $34.6(8.7,126)$ & $41.4(11.6,181)$ & $35(9.7,117)$ & $30.3(7.5,159)$ & $34.9(9.1,123)$ \\
\hline Adjusted iAs $s^{\prime \prime \prime}$ b & $0(0,14.9)$ & $0(0,10.9)$ & $3.5(0,67.6)$ & $0(0,50.5)$ & $0(0,48.3)$ & $0(0,27.7)$ \\
\hline Adjusted iAs ${ }^{\vee}$ & $0.6(0,33.4)$ & $1.3(0,36.5)$ & $5.5(0,98.1)$ & $6.1(0,123)$ & $1.8(0,67.5)$ & $2.5(0,77.4)$ \\
\hline Adjusted iAs & $2.7(0,51.6)$ & $3.1(0,48.9)$ & $15.2(0.8,142)$ & $12.6(0,156)$ & $6.5(0,98.9)$ & $5.7(0,104)$ \\
\hline Adjusted MMA & $1.7(0,36)$ & $2.6(0,24.4)$ & $8.2(0.4,76.6)$ & $8.3(0.1,72.5)$ & $3.8(0,57.9)$ & $4.3(0,52.5)$ \\
\hline Adjusted DMA & $43.2(13.8,369)$ & $52.8(21.2,276)$ & $114(30.1,577)$ & $126(39,776)$ & $65.1(17.5,530)$ & $76.4(24.8,605)$ \\
\hline Adjusted U-As & $48.6(16.2,470)$ & $61.6(24.6,338)$ & $139(37.4,784)$ & $154(43.6,972)$ & $77.5(19.6,677)$ & $90.4(28.8,770)$ \\
\hline
\end{tabular}

a Proportions of urinary arsenic metabolites are presented as median and 5th-95th percentiles

${ }^{b}$ Concentrations of urinary arsenic metabolites are creatinine-adjusted ( $\mu \mathrm{g} / \mathrm{g}$-creatinine) and presented as median and 5 th-95th percentiles 


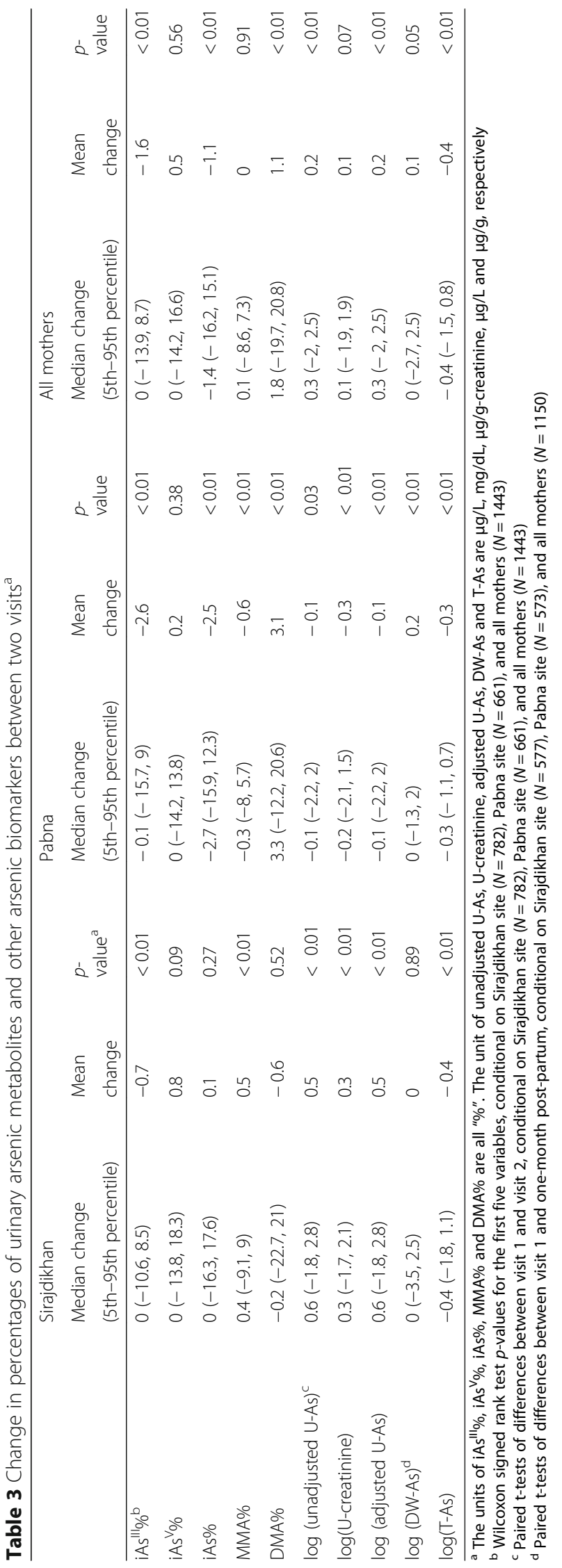




\section{dist \\ 0.00 .250 .500 .751 .00}

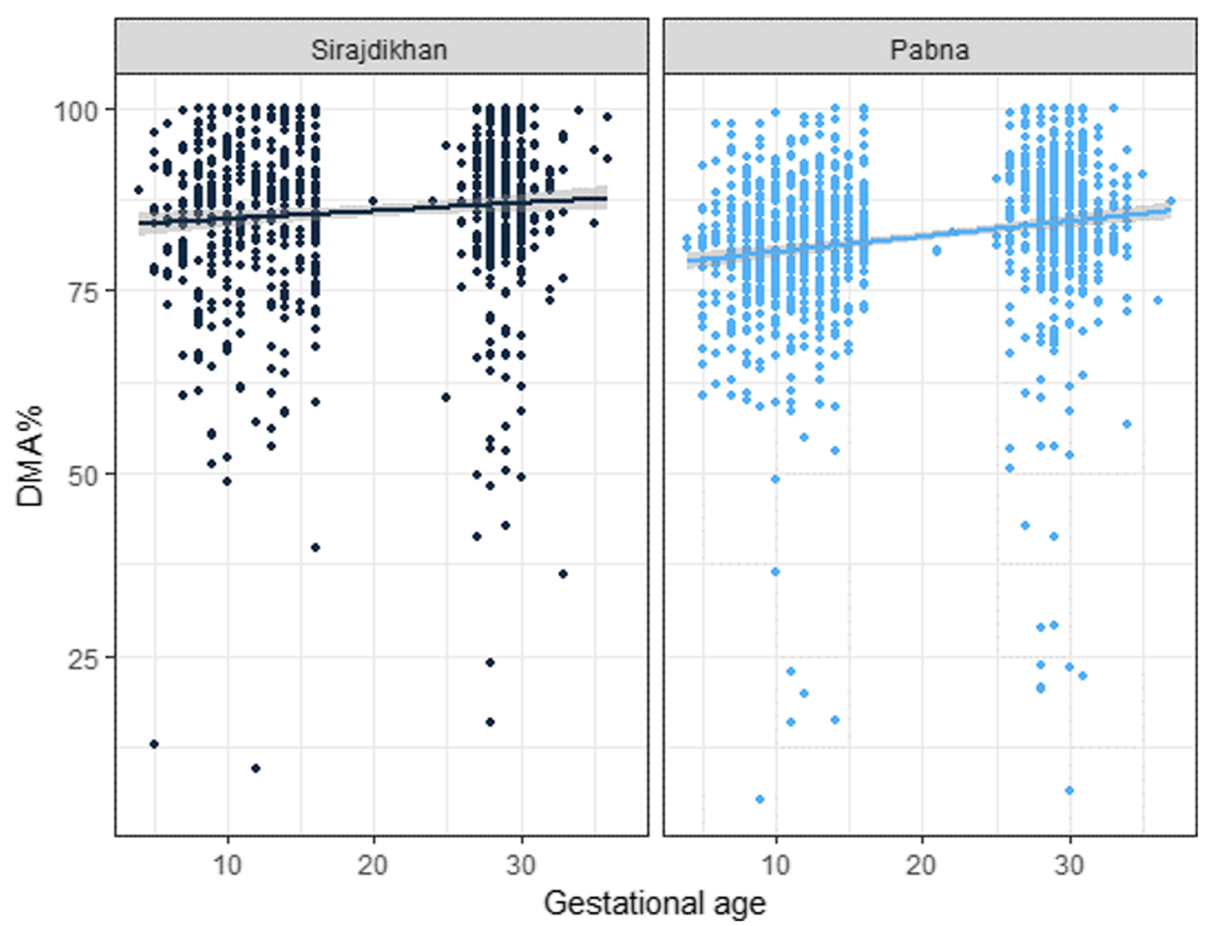

Fig. 1 Scatter plots of DMA\% and gestational weeks, restricted to participants with adjusted U-As > 50 $\mu \mathrm{g} / \mathrm{g}$-creatinine. [Figure legend: DMA\% (\%) plotted over gestational age (weeks), showing arsenic methylation efficiency of each participant at two repeated measurements. We applied a linear regression method to fit a solid line with the shade of standard error. We restricted exposure level to adjusted U-As $>50 \mu \mathrm{g} / \mathrm{g}$-creatinine, which is $\sim 25$ th percentile of adjusted U-As of both visits 1 and 2. Weeks of gestation was determined by ultrasound examination performed by trained healthcare workers. Dark blue dots indicate observations in Sirajdikhan; light blue dots indicate observations in Pabna]

arsenic from sea foods [49]. The exposure misclassification may bias water arsenic's true association between birth outcomes and developmental health outcomes. Spot urine arsenic level has limited ability to indicate long-term exposure, although it can be a good indicator of exposure from all sources including water.

Arsenic metabolism efficiency usually increases during pregnancy, particularly in the first trimester [31, 32]. Pregnant women usually have an ability to metabolize arsenic and excrete $70-100 \%$ of it as DMA in their urine, compared to an average of $60-80 \%$ for men and non-pregnant women [29]. We saw the same pattern in our cohort, especially when we restricted analysis to participants with higher arsenic exposure levels. DMA\% increased during the first trimester and remained high in the mid-to-late gestational period in our cohort. From our separate linear regression analyses by study visits, arsenic methylation efficiency was associated with gestational age at visit 1 but not at visit 2 . The physiological mechanism of these changes was not fully elucidated yet. Reduced $\mathrm{iAs}{ }^{\mathrm{III}} \%$ possibly contributed to the decreased iAs\%. However, as urine samples were not frozen immediately after collection, it is likely that some iAs ${ }^{\mathrm{III}}$ was oxidized to $\mathrm{iAs}^{\mathrm{V}}$. Thus, we focused our analysis on iAs\%, which is not affected by oxidation or reduction.

Other than DMA\%, U-As increased at follow-up visits, while DW-As remained unchanged. Toenail arsenic levels can represent the long-term internal dose of iAs over the past 3-6 months $[19,41]$. Thus, the two measurements taken at visit 1 and one-month post-partum demonstrate relative arsenic absorption in the time periods before visit 1 through mid-to-late gestation. Our observation of decreased T-As may indicate increased arsenic clearance during pregnancy, although additional evidence is needed to confirm an increase in arsenic excretion. Previous studies hypothesize that increased UAs is partially due to increased DMA\%, as DMAs are more readily excreted in urine $[31,32]$. However, after excluding outliers of adjusted U-As, we found a negative association between $\triangle \mathrm{DMA} \%$ (DMA\% difference between two visits) and $\Delta \mathrm{U}$-As (U-As difference between two visits) in linear regression $(\beta=-6.7, p<0.01)$, adjusted for age, BMI, education, income, and DW-As. The underlying reason is unclear. It indicates that the 


\section{Visit 1}

\section{Visit 2}

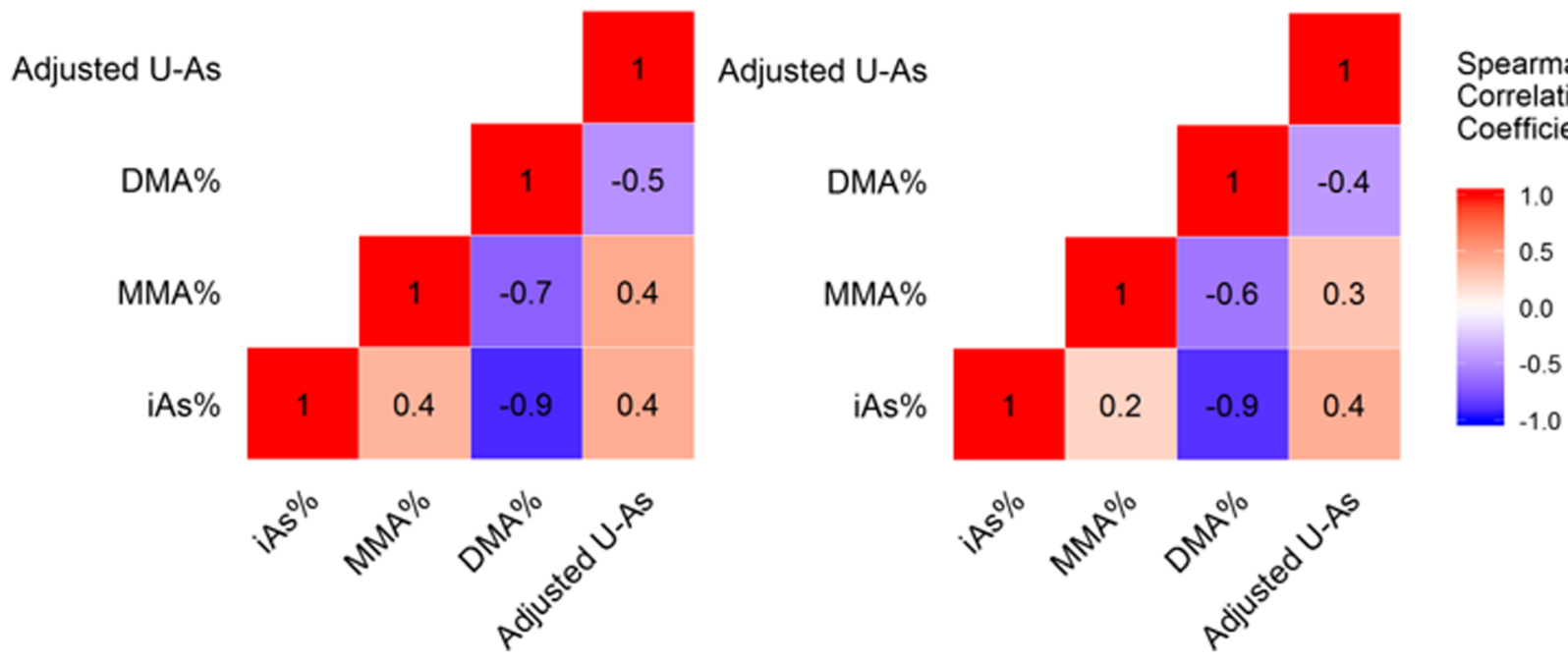

Fig. 2 Spearman correlation coefficients for arsenic metabolites at visit 1 and 2. [Figure legend: The unit of adjusted U-As is $\mu \mathrm{g} / \mathrm{g}$-creatinine, and the unit of iAs\%, MMA\% and DMA\% are all "\%". All Spearman correlation coefficients had $p<0.01$. The number of participants at visit 1 is 1605 , while the number of participants at visit 2 is 1443]
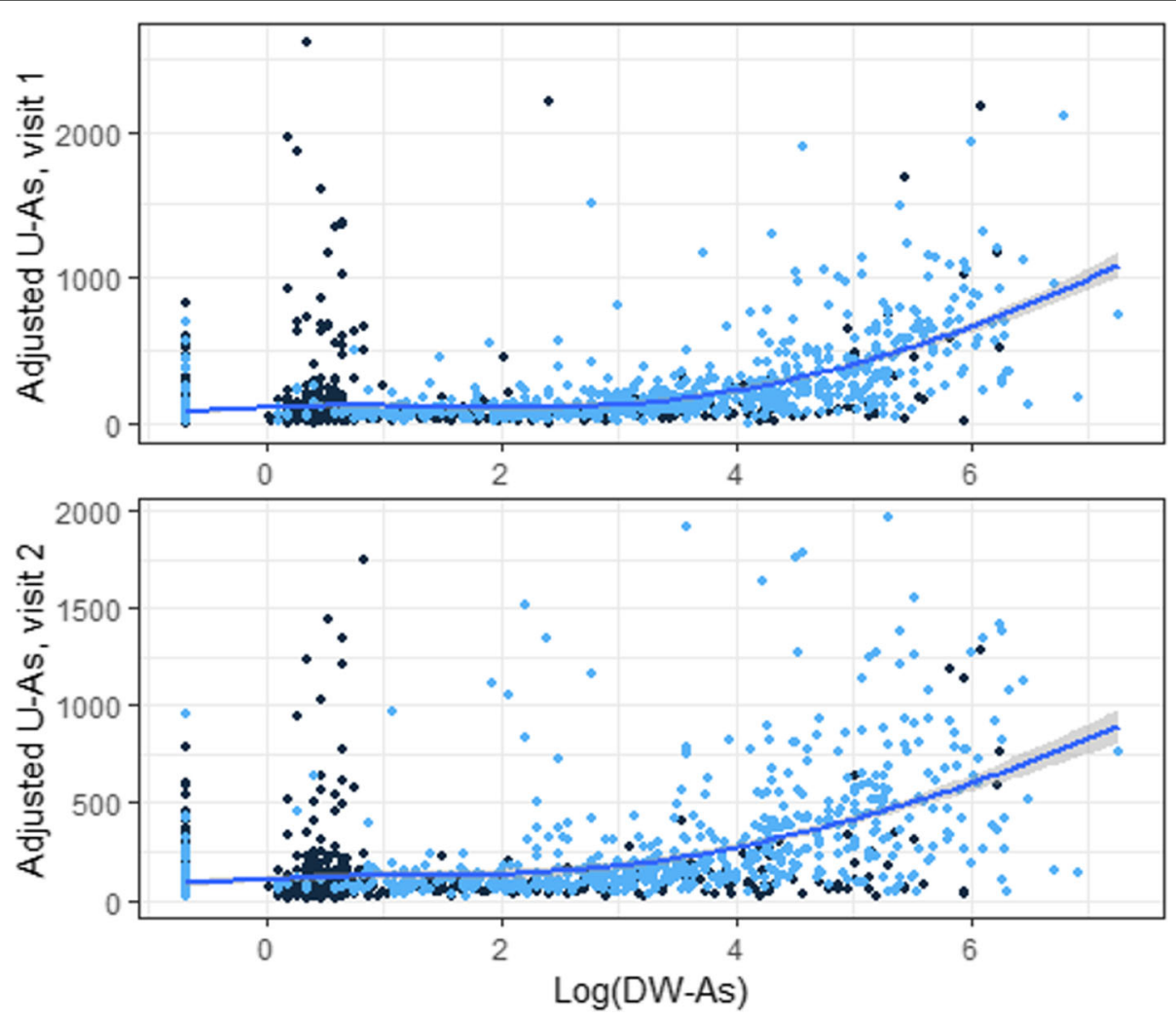

Fig. 3 Scatter plot of adjusted U-As over log-transformed DW-As. [Figure legend: Adjusted U-As (unit of adjusted U-As: $\mu g / g$-creatinine) was plotted over log-transformed DW-As (unit of DW-As: $\mu \mathrm{g} / \mathrm{L}$ ), showing the correlation between environmental arsenic exposure and arsenic excretion. We applied Loess local polynomial linear regression to fit a solid curve line with the shade of standard error. Dark blue dots indicate observations in Sirajdikhan; light blue dots indicate observations in Pabna] 


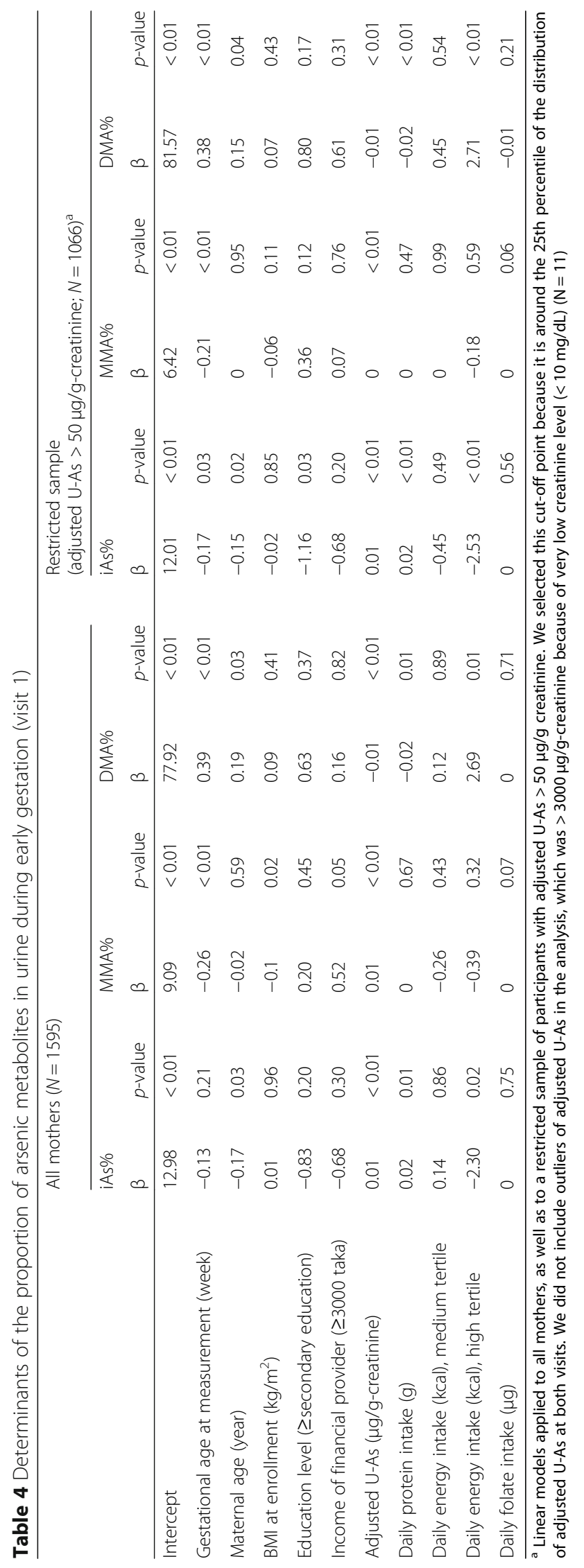


improvements of arsenic methylation efficiency may not results in higher arsenic excretion.

Folate plays a key role in one-carbon metabolism, which promotes synthesis of the methyl donor SAM [50]. Several epidemiological studies showed that folate supplementation in folate-deficient cohorts were associated with improved arsenic methylation efficiency and arsenic elimination [51-53]. Our data show that average daily folate intake of participants was $327 \mu \mathrm{g}$. The majority of participants had insufficient daily folate intake compared to the recommended dose of $400-800 \mu \mathrm{g}$. We were not able to compare folate intake level at visit 1 and 2, because the estimate was based on a self-reported FFQ for the past year. We hypothesized that dietary folate intake was positively associated with arsenic methylation efficiency, but we did not find an association at either visit from regression analyses. At visit 1 , participants had not yet received folate supplements, so diet was the main source of folate. This non-significant result about folate intake is in agreement with previous findings that folate levels during pregnancy marginally influence arsenic methylation [32, 34, 54]. At visit 2, every participant had been taking folate supplements, so there was less variation in participants' folate levels and thus a reduced ability to show any effect. The average daily protein intake was $172 \mathrm{~g}$ for all mothers, which is much higher than the US daily recommendation of 75$100 \mathrm{~g}$. Our method may overestimate the protein intake, but it represents the comparative protein intake among participants. Our study shows dietary intake of protein was associated with greater $\mathrm{iAs} \%$ in the first trimester, which indicates reduced methylation efficiency, adding to the inconsistent literature regarding protein intake and arsenic-related effects. Steinmaus et al. investigated a US population and found that people in the lower quartile of protein intake excreted a higher proportion of ingested iAs as MMA and a lower proportion as DMA, compared to the upper quartile of protein intake [54]. Some human studies have found worse arsenicassociated health effects among those consuming lower amounts of meat, eggs, and vegetables [55, 56]. KurziusSpencer et al. found that higher protein intake was associated with a decreased proportion of iAs in urine [57]. However, Heck et al. found that higher intake of protein, methionine, and cysteine was associated with 10-15\% greater total urinary arsenic excretion, after controlling for total energy intake, body weight, sex, age, tobacco use, and intake of other nutrients [58]. However, these studies did not properly address the complete biological role of protein intake. Inconsistent study results may be due to inaccurate measures or uncontrolled confounders. In addition, pregnant women compared with non-pregnant adults appear to have enhanced arsenic metabolism [34]. Therefore, factors affecting arsenic metabolism in non- pregnant women may not be applicable to our observations for pregnant women.

In addition, the association between DMA\% and protein intake may be slightly confounded by some highprotein dishes, as Lin et al. found that toenail arsenic level is positively associated with consumption of fish and meat items [59]. The effect of dietary protein and folate intake may also be confounded by body size, as participants with different body sizes may proportionally consume less or more food. Nonetheless, our multiple linear regression models adjusted for BMI, and we found similar results in our analyses with and without adjusting for total energy intake.

In this study, we used proportions of arsenic metabolites in urine to represent arsenic methylation efficiency, which is commonly used in epidemiological studies. Ratios between arsenic metabolites were not used here, as many pregnant women have very low proportions of iAs and MMA, resulting in extreme values. We also found similar results in sensitivity analysis on adjusted iAs concentrations ( $\mu \mathrm{g} / \mathrm{g}$-creatinine) and its determinants. Daily protein intake was positively associated with adjusted iAs concentration $(p=0.07)$, and the high tertile of daily energy intake had lower average iAs concentration $(p=0.69)$, adjusted for total urinary arsenic, age, BMI at enrollment, gestational age, education, and income of the financial provider.

Despite its strengths, our study also has several limitations. For instance, spot urine samples are only useful for reflecting short-term exposure. Although the percentage of arsenic metabolite is remarkably stable over time $[21,60]$, the time of day at sample collection may affect the observation of MMA\% and iAs\% [21, 61]. To minimize this confounding effect, healthcare workers in our study collected urine samples at a similar time of a day. Thus, while we did not control for bias from this confounder, it should not significantly bias the associations of arsenic methylation efficiency and its determinants. We observed good association between adjusted U-As and DW-As, indicating that adjusted U-As can be a reliable marker of exposure. Another limitation is that participants' dietary intake was self-reported and thus subject to reporting bias, especially when we asked about diet over a long period of 12 months. Protein intake was very high compared to the US Dietary Reference Intake for pregnant women [62, 63]. However, FFQs may not accurately capture absolute dietary intake or active dose of nutrients, although FFQs have strong validity in correctly ranking nutrition intake compared to a food diary that does not rely on recall and memory [64]. To mitigate the effects of measurement errors in self-reported FFQs, we controlled for energy intake in regression analyses. Further, although we have food intake amount, we are not able to quantify arsenic in the diet, which could 
help capture other arsenic sources. Additionally, we only focused on dietary folate and protein intake but lack information on intake of other nutrients related to onecarbon metabolism, including cysteine, methionine, choline, and vitamin B-12 [65]. Future studies should investigate whether these nutrients affect arsenic methylation efficiency during pregnancy and whether nutritional supplementation is beneficial for arsenic detoxification.

This is the first study to evaluate the association between arsenic methylation efficiency and dietary intake of protein and folate in pregnant women. Patterns of arsenic methylation efficiency and total urinary excretion during pregnancy may vary by geographical area, due to variations in demographics, lifestyle, and dietary habits. Therefore, the difference in arsenic methylation efficiency between our two study centers is not fully understood.

\section{Conclusions}

Our findings suggest that both arsenic methylation efficiency and total urinary arsenic level increase during pregnancy in a cohort of women in Bangladesh. The patterns of arsenic methylation efficiency and total arsenic excretion varied by geographic area. Also, we found that greater dietary intake of protein or folate may not improve arsenic methylation efficiency. Future research should continue to study potential approaches to improve health outcomes in populations exposed to arsenic.

\section{Supplementary information}

Supplementary information accompanies this paper at https://doi.org/10. 1186/s12940-019-0530-2.

Additional file 1: Table S1. Quantiles of adjusted urinary arsenic concentrations (U-As) ( $\mu \mathrm{g} / \mathrm{g}$ creatinine). Table S2. Determinants of the proportion of arsenic metabolites in urine in mid-to-late gestation (visit 2). Figure S1. Scatter plots of DMA\% and gestational weeks for all mothers. Figure S2. Correlation between adjusted U-As at visit 1 and visit 2. Figure S3. Association between unadjusted U-As and urinary creatinine at visit 1 (top) and visit 2 (bottom).

\section{Abbreviations}

BMI: Body mass index; DCH: Dhaka Community Hospital; DMA: Dimethyl forms of arsenic; DMA\%: Proportion of DMA in urine;

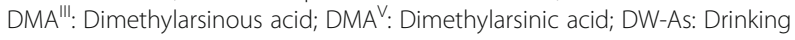
water arsenic level; FFQ: Food frequency questionnaire; iAs: Inorganic arsenic; iAs\%: Proportion of iAs in urine; iAs $s^{\prime \prime \prime}$ : Arsenite; iAs ${ }^{\mathrm{V}}$ : Arsenate; ICPMS: Inductively coupled process spectrometry; MMA: Monomethyl forms of arsenic; MMA\%: Proportion of MMA in urine; MMA ${ }^{\text {II: }}$ Monomethylarsonous acid; $M_{M} A^{\vee}$ : Monomethylarsonic acid; SAM: S-adenosyl methionine; TAs: Toenail arsenic level; U-As: Adjusted total urinary arsenic level

\section{Acknowledgements}

The authors acknowledge the cooperation of study participants and community healthcare workers of Bangladesh for their contributions to this study. We thank the lab manager, Li Su, and crew at Harvard T.H. Chan School of Public Health, as well as Dr. Yu-Mei Hsueh and her lab at Taipei Medical University for their hard work processing urine samples.

\section{Authors' contributions}

$\mathrm{DC}, \mathrm{LS}, \mathrm{GM}, \mathrm{QQ}$, and MR designed and conducted the Bangladesh Reproductive Study (Project Jeebon). SG designed the study of urinary arsenic metabolites during pregnancy. $\mathrm{YH}$ and her team contributed to urine sample analysis. SG and PL conducted statistical analyses. SG drafted the manuscript, and all authors contributed to its contents. All authors read and approved the final manuscript.

\section{Funding}

The design of Project Jeebon and its collection, analysis, data interpretation and manuscript writing were supported by National Institute of Environmental Health Sciences (NIEHS) grant R01 ES015533. This work was also supported by CDC (NIOSH) award 5T42OH008416.

\section{Availability of data and materials}

The datasets generated and analyzed during the current study are not publicly available due to institutional review board specifications (but are available from the corresponding author on reasonable request).

\section{Ethics approval and consent to participate}

All procedures were approved by Institutional Review Boards of both Harvard T.H. Chan School of Public Health and the Dhaka Community Hospital Trust. All participating families signed the informed consent of the study.

\section{Consent for publication}

Not applicable.

\section{Competing interests}

All authors of this study disclose that they do not have any actual or potential competing interests regarding the submitted article.

\section{Author details}

${ }^{1}$ Department of Environmental Health, Harvard T.H. Chan School of Public Health, 677 Huntington Ave, Boston, MA 02115, USA. ²Dhaka Community Hospital Trust, 190 Wireless Railgate, 1 Baro Moghbazar, Dhaka, Bangladesh. ${ }^{3}$ Harvard Medical School, Department of Population Medicine, Harvard Pilgrim Health Care Institute, 401 Park Drive, Suite 401, Boston, MA 02215, USA. ${ }^{4}$ Department of Family Medicine, Shuang Ho Hospital, Taipei Medical University, Taipei City, Taiwan. ${ }^{5}$ Department of Public Health, School of Medicine, College of Medicine, Taipei Medical University, No. 250, Wuxing Street, Xinyi District, Taipei City, Taiwan. ${ }^{6}$ Department of Epidemiology, Department of Environmental Health, Harvard T.H. Chan School of Public Health, 677 Huntington Ave, Boston, MA 02115, USA. ${ }^{7}$ Department of Biostatistics, Department of Environmental Health, Harvard T.H. Chan School of Public Health, 677 Huntington Ave, Boston, MA 02115, USA. ${ }^{8}$ Pulmonary and Critical Care Unit, Department of Medicine, Massachusetts General Hospital, 55 Fruit St, Boston, MA 02114, USA.

Received: 3 January 2019 Accepted: 1 October 2019

Published online: 05 November 2019

References

1. Welch AH, A WS, Helsel DR, Focazio MJ. Arsenic in Ground-Water Resources of the United States: US Geological Survey: Fact Sheet; 2000. p. 063-00.

2. WHO. Arsenic in Drinking Water. 2007.

3. NRC NRC. Critical aspects of EPA's IRIS assessment of inorganic arsenic: interim report. Washington: The National Academies Press; 2013.

4. Navas-Acien A, Sharrett AR, Silbergeld EK, Schwartz BS, Nachman KE, Burke TA, et al. Arsenic exposure and cardiovascular disease: a systematic review of the epidemiologic evidence. Am J Epidemiol. 2005;162(11):1037-49.

5. Kile ML, Rodrigues EG, Mazumdar M, Dobson CB, Diao N, Golam M, et al. A prospective cohort study of the association between drinking water arsenic exposure and self-reported maternal health symptoms during pregnancy in Bangladesh. Environ Health. 2014;13(1):29.

6. DeSesso JM, Jacobson CF, Scialli AR, Farr CH, Holson JF. An assessment of the developmental toxicity of inorganic arsenic. Reprod Toxicol. 1998;12(4):385-433

7. Naujokas MF, Anderson B, Ahsan H, Aposhian HV, Graziano JH, Thompson C, et al. The broad scope of health effects from chronic arsenic exposure: update on a worldwide public health problem. Environ Health Perspect. 2013;121(3):295-302. https://doi.org/10.1289/ehp.1205875 Epub 2013 Jan 3. 
8. Hopenhayn C, Bush HM, Bingcang A, Hertz-Picciotto I. Association between arsenic exposure from drinking water and anemia during pregnancy. J Occup Environ Med. 2006;48(6):635-43.

9. Kile ML, Cardenas A, Rodriques E, Mazumdar M, Dobson C, Golam M, et al. Estimating effects of arsenic exposure during pregnancy on perinatal outcomes in a Bangladeshi cohort. Epidemiology. 2016;27(2):173-81.

10. Ahmad SA, Sayed MH, Barua S, Khan MH, Faruquee MH, Jalil A, et al. Arsenic in drinking water and pregnancy outcomes. Environ Health Perspect. 2001; 109(6):629-31.

11. Bloom MS, Surdu S, Neamtiu IA, Gurzau ES. Maternal arsenic exposure and birth outcomes: a comprehensive review of the epidemiologic literature focused on drinking water. Int J Hyg Environ Health. 2014;217(7):709-19.

12. Cherry N, Shaikh K, McDonald C, Chowdhury Z. Stillbirth in rural Bangladesh: arsenic exposure and other etiological factors: a report from Gonoshasthaya Kendra. Bull World Health Organ. 2008;86(3):172-7.

13. Chou WC, Chung YT, Chen HY, Wang CJ, Ying TH, Chuang CY, et al. Maternal arsenic exposure and DNA damage biomarkers, and the associations with birth outcomes in a general population from Taiwan. PLoS One. 2014;9(2):e86398.

14. Quansah R, Armah FA, Essumang DK, Luginaah I, Clarke E, Marfoh K, et al. Association of arsenic with adverse pregnancy outcomes/infant mortality: a systematic review and meta-analysis. Environ Health Perspect. 2015;123(5):412-21.

15. Rahman A, Vahter M, Smith AH, Nermell B, Yunus M, El Arifeen S, et al. Arsenic exposure during pregnancy and size at birth: a prospective cohort study in Bangladesh. Am J Epidemiol. 2009;169(3):304-12.

16. Rahman A, Persson L, Nermell B, El Arifeen S, Ekström EC, Smith AH, et al. Arsenic exposure and risk of spontaneous abortion, stillbirth, and infant mortality. Epidemiology. 2010;21(6):797-804.

17. Yang CY, Chang CC, Tsai SS, Chuang HY, Ho CK, Wu TN. Arsenic in drinking water and adverse pregnancy outcome in an arseniasis-endemic area in northeastern Taiwan. Environ Res. 2003;91(1):29-34.

18. Vahter M. Mechanisms of arsenic biotransformation. Toxicology. 2002; 181-182:211-7.

19. ATSDR U. Toxicological profile for arsenic. Atlanta: Agency for Toxic Substances and Disease Registry, Division of Toxicology; 2007.

20. Alauddin M, Alauddin ST, Bhattacharjee M, Sultana S, Chowdhury D, Bibi H, et al. Speciation of arsenic metabolite intermediates in human urine by ionexchange chromatography and flow injection hydride generation atomic absorption spectrometry. J Environ Sci Health A Tox Hazard Subst Environ Eng. 2003;38(1):115-28

21. Concha G, Vogler G, Nermell B, Vahter M. Intra-individual variation in the metabolism of inorganic arsenic. Int Arch Occup Environ Health. 2002;75(8):576-80

22. Concha G, Nermell B, Vahter MV. Metabolism of inorganic arsenic in children with chronic high arsenic exposure in northern Argentina. Environ Health Perspect. 1998;106(6):355-9.

23. Tam GK, Charbonneau SM, Lacroix G, Bryce F. In vitro methylation of 74As in urine, plasma and red blood cells of human and dog. Bull Environ Contam Toxicol. 1979;22(1-2):69-71.

24. Buchet JP, Lauwerys $\mathrm{R}$, Roels $\mathrm{H}$. Comparison of the urinary excretion of arsenic metabolites after a single oral dose of sodium arsenite, monomethylarsonate, or dimethylarsinate in man. Int Arch Occup Environ Health. 1981;48(1):71-9.

25. Buchet JP, Lauwerys $\mathrm{R}$, Roels $\mathrm{H}$. Urinary excretion of inorganic arsenic and its metabolites after repeated ingestion of sodium metaarsenite by volunteers. Int Arch Occup Environ Health. 1981;48(2):111-8.

26. Gelmann ER, Gurzau E, Gurzau A, Goessler W, Kunrath J, Yeckel CW, et al. A pilot study: the importance of inter-individual differences in inorganic arsenic metabolism for birth weight outcome. Environ Toxicol Pharmacol. 2013;36(3):1266-75.

27. Vahter M, Concha G. Role of metabolism in arsenic toxicity. Pharmaco Toxicol. 2001;89(1):1-5

28. Jansen RJ, Argos M, Tong L, Li J, Rakibuz-Zaman M, Islam MT, et al. Determinants and consequences of arsenic metabolism efficiency among 4,794 individuals: demographics, lifestyle, genetics, and toxicity. Cancer Epidemiol Biomark Prev. 2016;25(2):381-90.

29. Tseng $\mathrm{CH}$. A review on environmental factors regulating arsenic methylation in humans. Toxicol Appl Pharmacol. 2009;235(3):338-50.

30. Gao S, Mostofa MG, Quamruzzaman Q, Rahman M, Rahman M, Su L, et al. Gene-environment interaction and maternal arsenic methylation efficiency during pregnancy. Environ Int. 2019;125:43-50. https://doi.org/10.1016/j. envint.2019.01.042 Epub Jan 28.

31. Hopenhayn C, Huang B, Christian J, Peralta C, Ferreccio C, Atallah R, et al. Profile of urinary arsenic metabolites during pregnancy. Environ Health Perspect. 2003;111(16):1888-91.

32. Gardner RM, Nermell B, Kippler M, Grandér M, Li L, Ekström EC, et al. Arsenic methylation efficiency increases during the first trimester of pregnancy independent of folate status. Reprod Toxicol. 2011;31(2):210-8.

33. Christian WJ, Hopenhayn C, Centeno JA, Todorov T. Distribution of urinary selenium and arsenic among pregnant women exposed to arsenic in drinking water. Environ Res. 2006;100(1):115-22.

34. Li L, Ekström EC, Goessler W, Lönnerdal B, Nermell B, Yunus M, et al. Nutritional status has marginal influence on the metabolism of inorganic arsenic in pregnant Bangladeshi women. Environ Health Perspect. 2008; 116(3):315-21.

35. WHO. Arsenic in tube well water in Bangladesh: health and economic impacts and implications for arsenic mitigation. Bull World Health Organ. 2012;90:839-46.

36. Rodrigues EG, Bellinger DC, Valeri L, Hasan MO, Quamruzzaman Q, Golam $\mathrm{M}$, et al. Neurodevelopmental outcomes among 2- to 3-year-old children in Bangladesh with elevated blood lead and exposure to arsenic and manganese in drinking water. Environmental Health. 2016;15(1):44 (1476069X (Electronic)).

37. Lin PD, Bromage S, Mostofa MG, Allen J, Oken E, Kile ML, et al. Validation of a Dish-Based Semiquantitative Food Questionnaire in Rural Bangladesh. Nutrients. 2017:9(1):49. https://doi.org/10.3390/nu9010049.

38. Chung J-Y, Lim H-J, Kim Y-J, Song K-H, Kim B-G, SJEh HY, et al. The separation of arsenic metabolites in urine by high performance liquid chromatographyinductively coupled plasma-mass spectrometry. 2014;29: e2014018.

39. Hsueh YM, Chiou HY, Huang YL, Wu WL, Huang CC, Yang MH, et al. Serum beta-carotene level, arsenic methylation capability, and incidence of skin cancer. Cancer Epidemiol Biomark Prev. 1997;6(8):589-96.

40. Hsueh YM, Hsu MK, Chiou HY, Yang MH, Huang CC, Chen CJ. Urinary arsenic speciation in subjects with or without restriction from seafood dietary intake. Toxicol Lett. 2002;133(1):83-91.

41. Kile ML, Houseman EA, Breton CV, Quamruzzaman Q, Rahman M,

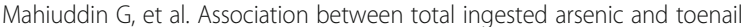
arsenic concentrations. J Environ Sci Health A Tox Hazard Subst Environ Eng. 2007:42(12):1827-34. https://doi.org/10.1080/10934520701566819.

42. Huyck KL, Kile ML, Mahiuddin G, Quamruzzaman Q, Rahman M, Breton CV, et al. Maternal arsenic exposure associated with low birth weight in Bangladesh. J Occup Environ Med. 2007;49(10):1097-104.

43. Shaheen N. Food composition tables for Bangladesh. Final Research Results. 2013;187. http://www.fao.org/fileadmin/templates/food_composition/ documents/FCT_10_2_14_final_version.pdf.

44. Hopenhayn-Rich C, Biggs ML, Kalman DA, Moore LE, Smith AH. Arsenic methylation patterns before and after changing from high to lower concentrations of arsenic in drinking water. Environ Health Perspect. 1996; 104(11):1200-7.

45. Kurttio $\mathrm{P}$, Komulainen $\mathrm{H}$, Hakala $\mathrm{E}$, Kahelin $\mathrm{H}$, Pekkanen J. Urinary excretion of arsenic species after exposure to arsenic present in drinking water. Arch Environ Contam Toxicol. 1998;34(3):297-305.

46. Styblo M, Del Razo LM, LeCluyse EL, Hamilton GA, Wang C, Cullen WR, et al. Metabolism of arsenic in primary cultures of human and rat hepatocytes. Chem Res Toxicol. 1999;12(7):560-5. https://doi.org/10.1021/tx990050l.

47. Karagas MR, Punshon T, Sayarath V, Jackson BP, Folt CL, Cottingham KL. Association of Rice and Rice-Product Consumption with Arsenic Exposure Early in life. JAMA Pediatr. 2016;170(6):609-16.

48. Meharg AA, Rahman MM. Arsenic contamination of Bangladesh paddy field soils: implications for rice contribution to arsenic consumption. Environ Sci Technol. 2003:37(2):229-34

49. Taylor V, Goodale B, Raab A, Schwerdtle T, Reimer K, Conklin S, et al. Human exposure to organic arsenic species from seafood. Sci Total Environ. 2017; 580:266-82

50. Gamble MV, Liu X, Ahsan H, Pilsner R, llievski V, Slavkovich V, et al. Folate, homocysteine, and arsenic metabolism in arsenic-exposed individuals in Bangladesh. Environ Health Perspect. 2005;113(12):1683-8.

51. Gamble MV, Liu X, Ahsan H, Pilsner JR, Ilievski V, Slavkovich V, et al. Folate and arsenic metabolism: a double-blind, placebo-controlled folic acidsupplementation trial in Bangladesh. Am J Clin Nutr. 2006;84(5):1093-101. 
52. Gamble MV, Liu X, Slavkovich V, Pilsner JR, llievski V, Factor-Litvak P, et al. Folic acid supplementation lowers blood arsenic. Am J Clin Nutr. 2007;86(4):1202-9.

53. Peters BA, Hall MN, Liu X, Parvez F, Sanchez TR, van Geen A, et al. Folic acid and Creatine as therapeutic approaches to lower blood arsenic: a randomized controlled trial. Environ Health Perspect. 2015;123(12):1294-301.

54. Steinmaus C, Carrigan K, Kalman D, Atallah R, Yuan Y, Smith AH. Dietary intake and arsenic methylation in a U.S. population. Environ Health Perspect. 2005;113(9):1153-9.

55. Hoffman DJ, Sanderson CJ, LeCaptain L, Cromartie E, Pendleton GW. Interactive effects of arsenate, selenium, and dietary protein on survival, growth, and physiology in mallard ducklings. Arch Environ Contam Toxicol. 1992;22(1):55-62

56. Vahter M, Marafante E. Effects of low dietary intake of methionine, choline or proteins on the biotransformation of arsenite in the rabbit. Toxicol Lett. 1987;37(1):41-6.

57. Kurzius-Spencer M, da Silva V, Thomson CA, Hartz V, Hsu CH, Burgess IL, et al. Nutrients in one-carbon metabolism and urinary arsenic methylation in the National Health and Nutrition Examination Survey (NHANES) 20032004. Sci Total Environ. 2017;607-608:381-90. https://doi.org/10.1016/ jscitotenv201707019 Epub Jul 27.

58. Heck JE, Nieves JW, Chen Y, Parvez F, Brandt-Rauf PW, Graziano JH, et al. Dietary intake of methionine, cysteine, and protein and urinary arsenic excretion in Bangladesh. Environ Health Perspect. 2009;117(1):99-104. https://doi.org/10.1289/ehp.11589 Epub 2008 Aug 22.

59. Lin PD, Bromage S, Mostofa MG, Allen J, Oken E, Kile ML, et al. Associations between Diet and Toenail Arsenic Concentration among Pregnant Women in Bangladesh: A Prospective Study. Nutrients. 2017;9(4):420. https://doi.org/ 10.3390/nu9040420.

60. Steinmaus C, Yuan Y, Kalman D, Atallah R, Smith AH. Intraindividual variability in arsenic methylation in a U.S. population. Cancer Epidemiol Biomark Prev. 2005;14(4):919-24.

61. Kile ML, Hoffman E, Hsueh YM, Afroz S, Quamruzzaman Q, Rahman M, et al. Variability in biomarkers of arsenic exposure and metabolism in adults over time. Environ Health Perspect. 2009;117(3):455-60. https://doi.org/10.1289/ ehp.11251 Epub 2008 Nov 19.

62. Finglas PM. Dietary reference intakes for thiamin, riboflavin, niacin, vitamin B 6, folate, vitamin B 12, pantothenic acid, biotin and choline: Elsevier; 2000.

63. Trumbo P, Schlicker S, Yates AA, Poos M. Dietary reference intakes for energy, carbohydrate, fiber, fat, fatty acids, cholesterol, protein and amino acids. J Am Diet Assoc. 2002;102(11):296-97. https://doi.org/10.1016/S09242244(01)00010-3.

64. Beck KL, Houston ZL, SA MN, Kruger R. Development and evaluation of a food frequency questionnaire to assess nutrient intakes of adult women in New Zealand. Nutrition \& Dietetics. 2018.

65. Heck JE, Gamble MV, Chen Y, Graziano JH, Slavkovich V, Parvez F, et al. Consumption of folate-related nutrients and metabolism of arsenic in Bangladesh. Am J Clin Nutr. 2007:85(5):1367-74. https://doi.org/10.1111/ 1747-0080.12472.

\section{Publisher's Note}

Springer Nature remains neutral with regard to jurisdictional claims in published maps and institutional affiliations.

Ready to submit your research? Choose BMC and benefit from:

- fast, convenient online submission

- thorough peer review by experienced researchers in your field

- rapid publication on acceptance

- support for research data, including large and complex data types

- gold Open Access which fosters wider collaboration and increased citations

- maximum visibility for your research: over $100 \mathrm{M}$ website views per year

At BMC, research is always in progress.

Learn more biomedcentral.com/submissions 